\title{
Islamic Branding, Viral Marketing, Online Consumer Review, and Purchasing Decision: The Mediating Role of Purchase Intention
}

\author{
Ayu Wandira $^{1^{*}}$, Taufikur Rahman ${ }^{1}$ \\ ${ }^{1}$ Faculty of Islamic Economics and Business, IAIN Salatiga, Indonesia
}

\begin{abstract}
This study aims to determine the effect of Islamic branding, viral marketing, and online consumer reviews on purchasing decisions on e-commerce Shopee with purchase intention as an intervening variable. This study uses quantitative methods with primary data obtained through the distribution of questionnaires. The data collection technique used the purposive sampling technique with the number of respondents as many as 96 respondents. The data analysis used includes instrument tests, statistical tests, classical assumption tests, and path analyses. Based on the test results show (1) Islamic branding has a positive and significant effect on purchasing decisions. (2) Viral marketing has a positive and significant effect on purchasing decisions. (3) Online consumer reviews have a negative and insignificant effect on purchasing decisions. (4) Purchase intention has a positive and significant effect on purchasing decisions. (5) Purchase intention can mediate Islamic branding on purchasing decisions. (6) Purchase intention is not able to mediate viral marketing on purchasing decisions. (7) Purchase intention is not able to mediate online consumer reviews of purchasing decisions.
\end{abstract}

Keywords: Islamic Branding, Viral Marketing, Online Consumer Review, Purchasing decisions, Purchase intention

\section{Introduction}

At the beginning of 2020, it began when the outbreak of the Covid-19 virus around the world caused all economic sectors in various countries to be paralyzed. Starting from retail companies, businesses, transportation, accommodation, all experienced a significant decline in revenue due to the Covid-19 pandemic and all economic activities had stopped. But on the other hand, e-commerce is more profitable, whereas the Covid-19 pandemic has increased ecommerce revenue (Katadata, 2020). Due to government policies to stay at home, keep distance, avoid crowds, people decide to shop online. During the pandemic, most people

* Corresponding author: takur067782@yahoo.co.id 


\section{$A I \overline{C E B} \quad$ Annual International Conference \\ on Islamic Economics and Business, 2021}

switched from shopping offline in stores to shopping online. They make online purchases to meet basic needs, health products, and household appliances.

Until the second quarter of 2020, internet users in Indonesia reached 196.7 million or $73.7 \%$ of the population, this number increased sharply compared to last year. The increase is supported by a fast and evenly distributed internet infrastructure and massive digital transformation due to the Covid-19 pandemic (APJJI, 2020). The use of the internet lately is often used for work, or online learning according to government policies that stipulate Work From Home (WFH) and School From Home (SFH), and the most widely used is online shopping on e-commerce. With the existence of e-commerce, it can make it easier for people to find products they want to buy via the internet efficiently, thus saving time. Lately, ecommerce had a relative interest, this makes e-commerce a new market for consumers and producers amid during in a pandemic.

Based on data compiled by the We Are Social research agency in April 2020, it shows that e-commerce users during the Covid-19 pandemic, most consumers used to shop online at supermarkets, which increased to $251 \%$, on the contrary, the tourism sector decreased by $-72 \%$. This is an opportunity for e-commerce business because the internet provides business convenience for consumers and producers.

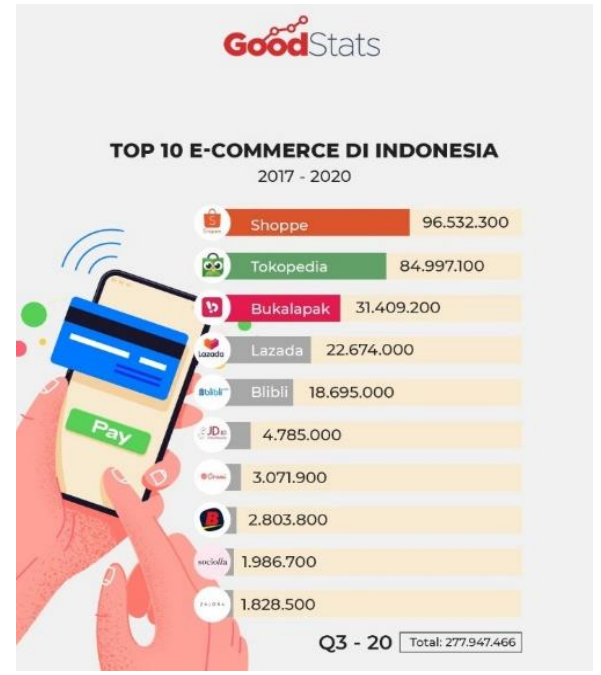

Fig 1. Top 10 E-Commerce in Indonesia

Source: GNFI (2021)

From the data above, it can be concluded that in 2020 the top entry e-commerce business in Indonesia is Shopee from Singapore. Shopee has successfully passed Tokopedia as an ecommerce site that is visited by many Indonesian e-commerce users. This makes the benchmark that the Indonesian people have a high interest in the e-commerce business. Shopee is the leading e-commerce platform in Southeast Asia under the auspices of the SEA Group, which was founded in 2009 by Forrest Li. Shopee was launched in 2015 in Singapore, and has since expanded its network to Malaysia, Thailand, Taiwan, Indonesia, Vietnam, and the Philippines. In 2017, Shopee's Gross Merchandise Value (GMV) reached US\$1.6 billion, up $206 \%$ from the previous year. Shopee's total GMV in 2018 was US $\$ 2.7$ billion, up $153 \%$ from 2017 (Shopee, 2021).

Based on data from Globalreligiusfuture, Indonesia is the largest Muslim country in the world, Indonesia's Muslim population reaches 256,820,000 people (Katadata, 2020). This is a potential market for producers to attract Muslim consumers in Indonesia. Muslim consumers must act selectively in choosing and consuming products, because even the halal 


\section{$A I \bar{C} \quad$ Annual International Conference \\ on Islamic Economics and Business, 2021}

label does not necessarily guarantee the halalness of the product. The producers are aware that Muslim consumers are the target market for product marketing. One of the strategies implemented is Islamic Branding or the use of names related to Islam, and showing the halal identity of a product (Nasrullah, 2015). According to research conducted by Snapchat during the Ramadan 2020 survey period and the Covid-19 pandemic with 1000 respondents, $66 \%$ of respondents chose the Shopee marketplace as the most memorable e-commerce (top of mind), because of good branding will build consumer loyalty to use the marketplace (Rakhma et al., 2021).

The current phenomenon makes consumers tend to need information that is fast and precise, but can be obtained in a short time for the products they want. The presence of Viral Marketing can help business actors to introduce products more effectively and quickly to consumers. Viral Marketing is a form of marketing technique used by companies to spread messages using social media (Nggilu et al., 2019). The widespread use of social media such as Instagram, Tiktok, Facebook is used by business actors to promote and introduce their products. The most popular social media platform for millennials and gen $\mathrm{Z}$ is Tiktok, with its main characteristic being video content. Tiktok is now one of the social media that has great potential and functions as a marketing tool for e-commerce businesses with viral marketing techniques. Tiktok video content with the hashtag \#shopeehaul or \#racunshopee is always busy being sought and used by consumers and producers.

In addition to Islamic Branding which is good for increasing consumer loyalty, and Viral Marketing is used by many e-commerce such as Shopee for product marketing. Shopee has an Online Consumer Review feature, which is in the form of criticism, suggestions, and product reviews, and all things that are expected regarding the product be purchased, from the available information other consumers can use it in digging up product information they will buy. Online Consumer Review deserves to be studied because it can be used as a promotional tool that is considered the most credible by consumers. It also helps consumers to answer consumer curiosity regarding the product so that it can assist consumers in making purchasing decisions (Febriana \& Yulianto, 2018).

Based on research that has been carried out previously, there are differences in research results. Research conducted by Trishananto (2019) and Prihanti (2019) shows that the Islamic Branding variable has a positive and significant influence on consumer purchasing decisions. While the results of Hidayati's research (2018), show that Islamic branding does not affect on purchasing decisions. Previous research on viral marketing variables and purchasing decisions, Nggilu et al. (2019) and Maulani \& Sanawiri (2019) stated that viral marketing has a significant positive effect on purchasing decisions at shopee. However, Purwanto's research (2019) shows that viral marketing has no influence on purchasing decisions. Then in Damayanti's research (2019) and Rakhma et al. (2021) it is stated that online consumer reviews have a positive and significant influence on purchasing decisions, while Sari's research (2019) states that online consumer reviews have no effect on purchasing decisions. According to Sriyanto \& Kuncoro (2019)) and Solihin (2020) stated that buying interest has a significant positive effect on purchasing decisions. In addition, Montjai et al. (2014) revealed that buying interest has no effect on purchasing decisions.

There are differences in the results of previous studies, it is possible that there are other variables that influence the relationship between Islamic Branding, viral marketing and online consumer reviews with purchasing decisions. In this study, the purchase intention variable is added as an intervening variable. Intervening variables are variables that theoretically affect the relationship between the dependent variable and the independent variable into an indirect relationship (Sugiyono, 2013). It is hoped that the purchase intention variable can make the influence of the Islamic Branding, viral marketing and online consumer review variables on the purchasing decision variable indirectly but through the intervening variable purchase intention. 


\section{Literature Review}

\subsection{Technology Acceptance Model (TAM)}

The Technology Acceptance Model (TAM) is one of the models used in information technology research, marketing, industrial organizations, first introduced by Davis in 1986. Several empirical studies have found that TAM consistently explains the comparison of the desire to use a technology (usage intention) and behavior (behavior). In dealing with the COVID-19 pandemic, a technological innovation strategy is needed, especially an understanding of TAM acceptance (Simanjuntak \& Sukresna, 2020).

According to Rauniar et al. (2014), the TAM model supports all hypotheses regarding internet and social media usage behavior. This provides evidence of the importance of TAM in considering internet user engagement on social media sites and business strategies such as e-commerce. The relevance of TAM with this research is to measure that TAM can describe the elements of consumer decisions in using a product in Shopee e-commerce

\subsection{Islamic Branding}

Islamic branding can be interpreted as the use of a name that contains Islamic elements or shows the halal identity of a product. Islamic branding influences consumer decisions on a product, Islamic branding as part of a product not only uses the name of Islam as a factor to attract consumers, but also in the selection of raw materials, production processes and others must be considered so that public trust will be formed which in the end will lead to loyalty (Trishananto, 2019).

According to Tjiptono (2001) a brand is needed for a product so that the product has high value, has usefulness for owners, consumers, and the community. The benefits of the brand include 1) making product search easier, 2) protecting a product before the law, 3) knowing the level of consumer satisfaction with the product, 4) being the hallmark of a product and distinguishing it from other products. Quality Measurement of Islamic Branding variables related to previous research by Yunus et al. (2014) namely: 1) Brand is a very important element, 2) Familiarity with the brand, 3) Consumer trust, 4) Halal labeling of a product

\subsection{Viral Marketing}

Viral Marketing comes from the term "virus" and comes from the image of someone who "infects" a marketing message and spreads it to others like a virus. Messages conveyed in viral marketing can be in the form of advertising, hyperlink promotions, online newsletters, streaming videos, and games (Dobele et al., 2005). Another opinion according to Kotler \& Keller (2008) Viral Marketing or viral marketing is another form of information from one mouse click to the next (word of mouse) that motivates buyers to review products and services or audio, video, and written information to others online. on line. The characteristics of viral marketing can be divided into two basic structures, namely Active Viral Marketing and Frictionless Viral Marketing (Skrob, 2005). Active Viral Marketing, closely related to the traditional Word of Mouth concept because users are personally involved directly in the process of attracting new consumers. 2) Frictionless Viral Marketing, in contrast to active viral marketing, the frictionless concept does not require the active participation of consumers to advertise or disseminate information about a product.

According to Furqon (2020) there are several advantages of promotion with viral marketing techniques including 1) Primary service, 2) Lower costs, 3) More efficient, 4) Continuous promotion opportunities. According to Skrob (2005), viral marketing indicators are 1) Recommendations, 2) Reference lists, 3) Affiliate Programs, 4) Search Engines 


\section{$A \mathrm{IC} \quad$ Annual International Conference \\ on Islamic Economics and Business, 2021}

\subsection{Online Consumer Review}

When shopping online, consumers are faced with many choices, but consumers only know little direct information about the product because they cannot touch or feel the product. So OCR is made to overcome this weakness, OCR provides relevant information to consumers. It is said to be relevant because OCR is carried out voluntarily and independently by consumers who have purchased the product without any intervention from the seller or company (Chou, 2012). Online consumer review is a feedback and recommendation from buyers who have felt the benefits of products and services, thus generating buying interest in potential consumers (Agustyan \& Baehaqi, 2020).

According to Mo et al. (2015) there are 6 requirements for OCR to be effective, including the following: 1) Usefulness of Online Consumer Reviews, from the large amount of information only valuable reviews will influence consumer decision making. 2) Reviewer Expertise, one of the special characteristics of online consumer reviews is that they are made by individuals whose names or identities are not known. 3) Timeliness of Online Consumer Review, in the information search process, consumers are faced with a large amount of relevant information that is put together with a certain time span. 4) Volume of Online Consumer Review, the number of comments or testimonials from a reviewer regarding a more specific product or service. 5) Valence of Online Consumer Review, the value of a message given in an online consumer review is divided into 2 categories, namely messages that contain all positive things (benefit) and vice versa, namely messages that contain negative things (benefit loss). 6) Comprehensiveness of Online Consumer Review, completeness in online consumer reviews is used to measure how detailed and complete a product is.

According to Lackermair et al. (2013), there are four online consumer review indicators, including Awareness, Frequency, Comparison, Effect.

\subsection{Purchasing Decisions}

According to Kotler \& Keller (2009), purchasing decisions are a person's behavior in buying or using a product, either in the form of a product that is believed to meet his needs or desires. According to Prihanti (2019), at the end point of a buying process, consumers will stop looking and stop evaluating a product or service to make a purchase decision. There are several factors forming purchasing decisions, Morissan (2012), defines them as follows: 1) The attitude of others, the extent to which the attitudes of others reduce a person's preferred alternative will depend on two things, namely the intensity of the other person's negative attitude towards the consumer's preferred alternative, and the consumer's motivation to comply with the wishes of others. 2) Unanticipated situations, these factors can arise and change the purchase value. A person may lose his job which causes him to buy another product that he feels is more urgent, or a shop assistant who is consulted turns out to discourage consumers from buying the desired product and suggesting another product or brand. 3) Perceived risk, the consumer's decision to modify, delay, or avoid purchasing decisions is strongly influenced by perceived risk. The size of the perceived risk varies depending on the amount of money spent, the amount of attribute uncertainty, and the amount of consumer confidence. To reduce risk, consumers do various things such as collecting information on a product. Therefore, the seller must understand the factors that can pose a risk by providing information and support to reduce the perceived risk. According to Kotler \& Keller (2009), there are indicators of purchasing decisions including 1) Product/service selection, 2) Brand selection, 3) Timing, 4) Choice of payment method/method. 


\section{$A \mathrm{IC} \overline{I E B}$ Annual International Conference \\ on Islamic Economics and Business, 2021}

\subsection{Purchase Intention}

According to Kotler (2005) buying interest is an attitude that is created after someone gets interested in a product they see, from these observations emerges an attraction to try and in the end the consumer wants and tries to have the product and then buys it. According to Schiffman \& Kanuk (2008), the motives of buyers (buying motives) in the formation of buying interest that will encourage them to make purchases are as follows: 1) Primary buying motive, which is the motive to buy the real thing, buyers shop for what they really need. 2) Selective buying motive, namely the purchase of goods with various considerations, for example, whether there are benefits, whether there are benefits. 3) Patronage buying motivation, buying by considering the place of purchase, for example at a certain store. 4) Purchase decision, after the consumer evaluates several alternatives, the consumer will make a purchase decision.

According to Tjiptono (2001), indicators of buying interest include the following: 1) Transactional interest, namely buying interest that arises when there is a tendency to buy products from consumers. 2) Referential interest, namely buying interest that arises when consumers can recommend products to others. 3) Preferential Interest, namely buying interest that arises when consumers make the product as the main choice. 4) Exploratory Interest, namely buying interest that arises when consumers are looking for more information about the product.

\section{Method}

This type of research is a field research with a quantitative approach. This study uses primary data obtained through the distribution of questionnaires. Sampling method with nonprobability sampling method, with purposive sampling technique. The measurement scale with a Likert scale of 1-10. The population in this study are Shopee e-commerce users in Salatiga City whose number is unknown. While the samples taken in this study are Muslim consumers who use Shopee in Salatiga City. To determine the size of the sample where the total population is unknown, then using the Riduwan formula in Octaviani (2021), this formula is the basic formula for determining sample size:

$$
\begin{aligned}
& \mathrm{n}=\left(\frac{\frac{Z a}{2} \cdot o^{\circ}}{\varepsilon}\right)^{2} \\
& \mathrm{n} \quad=\left(\frac{1,96 \cdot 0.25}{0,05}\right)^{2} \\
& \mathrm{n} \quad=96,04 \\
& \mathrm{n}=\text { Number of samples } \\
& \mathrm{Z} \alpha / 2=\mathrm{Z} \text { value is a } 95 \% \text { confidence level, which is } 1.96 \\
& \sigma \quad=\text { Population standard deviation (estimated sample } 0.5 \times 0.5=0.25 \text { ) } \\
& \text { e } \quad=5 \% \text { error rate }
\end{aligned}
$$

With the calculation above, the number of samples obtained is 96 . So this study uses a sample of 96, consisting of Muslim consumers who use shopee in Salatiga. 


\section{Result and Discussion}

\subsection{Instrument Test}

\subsubsection{Reliability Test}

The results of the reliability test in this study are described in the following table:

Table 1. Reliability Test Results

\begin{tabular}{|l|l|l|}
\hline Variabel & Cronbach Alpha & Keterangan \\
\hline Islamic Branding (X1) & 0,930 & Reliable \\
\hline Viral Marketing (X2) & 0,934 & Reliable \\
\hline Online Consumer Review (X3) & 0,899 & Reliable \\
\hline Purchasing Decisions (Y) & 0,884 & Reliable \\
\hline Purchase Intention (Z) & 0,872 & Reliable \\
\hline
\end{tabular}

Source: Primary data is processed, 2021

From the table above, it is known that all variables have a Cronbach alpha value greater than 0.60 . This indicates that the construct in the questionnaire is reliable or reliable.

\subsubsection{Validity Test}

Table 2. Validity Test Results

\begin{tabular}{|c|c|c|c|c|}
\hline Variabel & Item & $r$ hitung & $\mathrm{r}$ tabel & Keterangan \\
\hline \multirow{4}{*}{$\begin{array}{c}\text { Islamic } \\
\text { Branding }(X 1)\end{array}$} & Question 1 & 0,898 & \multirow{4}{*}{0,2006} & Valid \\
\hline & Question 2 & 0,915 & & Valid \\
\hline & Question 3 & 0,942 & & Valid \\
\hline & Question 4 & 0,908 & & Valid \\
\hline \multirow{4}{*}{$\begin{array}{c}\text { Viral } \\
\text { Marketing }(X 2)\end{array}$} & Question 1 & 0,955 & \multirow{4}{*}{0,2006} & Valid \\
\hline & Question 2 & 0,913 & & Valid \\
\hline & Question 3 & 0,902 & & Valid \\
\hline & Question 4 & 0,888 & & Valid \\
\hline \multirow{4}{*}{$\begin{array}{c}\text { Online } \\
\text { Consumer } \\
\text { Review }(X 3)\end{array}$} & Question 1 & 0,915 & \multirow{4}{*}{0,2006} & Valid \\
\hline & Question 2 & 0,895 & & Valid \\
\hline & Question 3 & 0,909 & & Valid \\
\hline & Question 4 & 0,788 & & Valid \\
\hline \multirow{4}{*}{$\begin{array}{c}\text { Purchasing } \\
\text { Decisons (Y) }\end{array}$} & Question 1 & 0,847 & \multirow{4}{*}{0,2006} & Valid \\
\hline & Question 2 & 0,920 & & Valid \\
\hline & Question 3 & 0,862 & & Valid \\
\hline & Question 4 & 0,843 & & Valid \\
\hline \multirow{4}{*}{$\begin{array}{c}\text { Purchase } \\
\text { Intention (Z) }\end{array}$} & Question 1 & 0,788 & \multirow{4}{*}{0,2006} & Valid \\
\hline & Question 2 & 0,904 & & Valid \\
\hline & Question 3 & 0,816 & & Valid \\
\hline & Question 4 & 0,788 & & Valid \\
\hline
\end{tabular}

Source: Primary data is processed, 2021

To compare the calculated $r$ value with the $r$ table, it is necessary to know that the $r$ table with degree of freedom $(\mathrm{df})=\mathrm{n}-2,(\mathrm{df})=96-2,(\mathrm{df})=94$ with a significance value of $5 \%$ or 0.05 , then the number is obtained $r$ table is 0.206 . From table 2 above, it is known that all question items for each variable have a value of $r$ table which is smaller than $r$ count, this indicates that all question items on the questionnaire are valid. 


\subsection{Statistic Test}

\subsection{1 t Test (Equation 1)}

To find out the results of the $t$ test can be seen in the following table:

Table 3. t-Test Results Equation 1

Coefficients $^{\text {a }}$

\begin{tabular}{|c|c|c|c|c|c|}
\hline \multirow[b]{2}{*}{ Model } & \multicolumn{2}{|c|}{$\begin{array}{l}\text { Unstandardized } \\
\text { Coefficients }\end{array}$} & $\begin{array}{l}\text { Standardized } \\
\text { Coefficients } \\
\end{array}$ & \multirow[b]{2}{*}{$\mathrm{t}$} & \multirow[b]{2}{*}{ Sig. } \\
\hline & $\mathrm{B}$ & Std. Error & Beta & & \\
\hline 1 (Constant) & 9,860 & 3,081 & & 3,200 & ,002 \\
\hline Islamic Branding (X1) &, 583 &, 133 & 633 & 4,390 &, 000 \\
\hline Viral Marketing (X2) &,- 037 & 142 &,- 035 &,- 258 & 797 \\
\hline $\begin{array}{l}\text { Online Consumer Review } \\
\text { (X3) }\end{array}$ & ,112 & , 127 &, 101 & ,884 & ,379 \\
\hline
\end{tabular}

a. Dependent Variable: Purchase Intention (Z)

Source: Primary data is processed, 2021

From table 3 above, the regression equation is obtained as follows:

$$
\mathrm{Z}=9,860+0,583 \mathrm{X} 1-0,037 \mathrm{X} 2+0,112 \mathrm{X} 3+e
$$

From the regression equation model above, it can be seen that the partial direct effect between the independent variables on the dependent is as follows:

1) A constant of 9.860 means that if the independent variable is considered constant, then purchase intention is worth 9.860 .

2) The Islamic branding coefficient (X1) of 0.583 has a positive value and a significant level of $0.000<0.05$ stating that Islamic branding (X1) has a positive and significant effect on purchase intention $(Z)$. This means that if Islamic branding is increased by one unit, then purchase intention will increase by 0.583 .

3) The viral marketing coefficient (X2) of -0.037 is negative and a significant level of 0.797 $>0.05$ means that viral marketing (X2) has a negative and insignificant effect on purchase intention $(Z)$. This means that if viral marketing increases by one unit, then purchase intention does not change.

4) The online consumer review coefficient (X3) of 0.112 is positive and a significant level of $0.379>0.05$ states that online consumer review (X3) has a positive and insignificant effect on purchase intention $(Z)$. This means that if the online consumer review increases by one unit, the purchase intention will not change.

\subsection{2 $\mathrm{t}$ Test (Equation 2)}

Table 4. T-Test Results Equation 2

Coefficients $^{\mathbf{a}}$

\begin{tabular}{|c|c|c|c|c|c|}
\hline \multirow[b]{2}{*}{ Model } & \multicolumn{2}{|c|}{$\begin{array}{c}\text { Unstandardized } \\
\text { Coefficients } \\
\end{array}$} & \multirow{2}{*}{$\begin{array}{c}\begin{array}{c}\text { Standardized } \\
\text { Coefficients }\end{array} \\
\text { Beta }\end{array}$} & \multirow[b]{2}{*}{$\mathrm{t}$} & \multirow[b]{2}{*}{ Sig. } \\
\hline & $\mathrm{B}$ & Std. Error & & & \\
\hline 1 (Constant) & $-1,753$ & 2,188 & &,- 801 &, 425 \\
\hline Islamic Branding (X1) &, 531 & ,098 &, 524 & 5,403 & 000 \\
\hline Viral Marketing (X2) & ,276 & ,096 & ,243 & 2,888 & 005 \\
\hline $\begin{array}{l}\text { Online Consumer Review } \\
\text { (X3) }\end{array}$ &,- 030 & ,086 &,- 025 &,- 350 & ,727 \\
\hline Purchase Intention $(\mathrm{Z})$ & ,264 & ,070 & ,240 & 3,758 &, 000 \\
\hline
\end{tabular}




\section{$A \mathrm{IC} \overline{\operatorname{IEB}}$ Annual International Conference \\ on Islamic Economics and Business, 2021}

a. Dependent Variable: Keputusan Pembelian (Y)

Source: Primary data is processed, 2021

From table 4 above, the regression equation is obtained as follows:

$$
\mathrm{Y}=-1,753+0,531 \mathrm{X} 1+0,276 \mathrm{X} 2-0,030 \mathrm{X} 3+0,264 \mathrm{Z}+e
$$

From the regression equation model above, it can be seen that the partial direct effect between the independent variables on the dependent is as follows:

1) The constant of -1.753 states that if the independent variable is considered constant, then the average purchase decision will decrease by 1.753 units.

2) The Islamic branding coefficient (X1) of 0.531 is positive and a significant level of 0.000 $<0.05$ states that Islamic branding (X1) has a positive and significant effect on purchasing decisions (Y). This means that if Islamic branding is reduced by one unit, the purchase decision will decrease by 0.531 .

3) The viral marketing coefficient (X2) of 0.276 is positive and a significant level of 0.005 $<0.05$ means that viral marketing (X2) has a positive and significant effect on purchasing decisions (Y). This means that if viral marketing is reduced by one unit, the purchase decision will decrease by 0.276 .

4) The online consumer review coefficient (X3) of - 0.030 is negative and a significant level of $0.727>0.05$ states that online consumer review (X3) has a negative and insignificant effect on purchasing decisions $(\mathrm{Y})$. This means that if the online consumer review is reduced by one unit, the purchase decision will not change.

5) The coefficient of purchase intention $(Z)$ of 0.264 is positive and a significant level of $0.000<0.05$ states that purchase intention $(Z)$ has a positive and significant effect on purchasing decisions (Y). This means that if purchase intention is reduced by one unit, then the purchase decision will decrease by 0.264 .

\subsection{Classis Assumption Test}

\subsubsection{Multicollinierity test (Equation 1)}

Table 5. Multicollinearity Test Results Equation 1

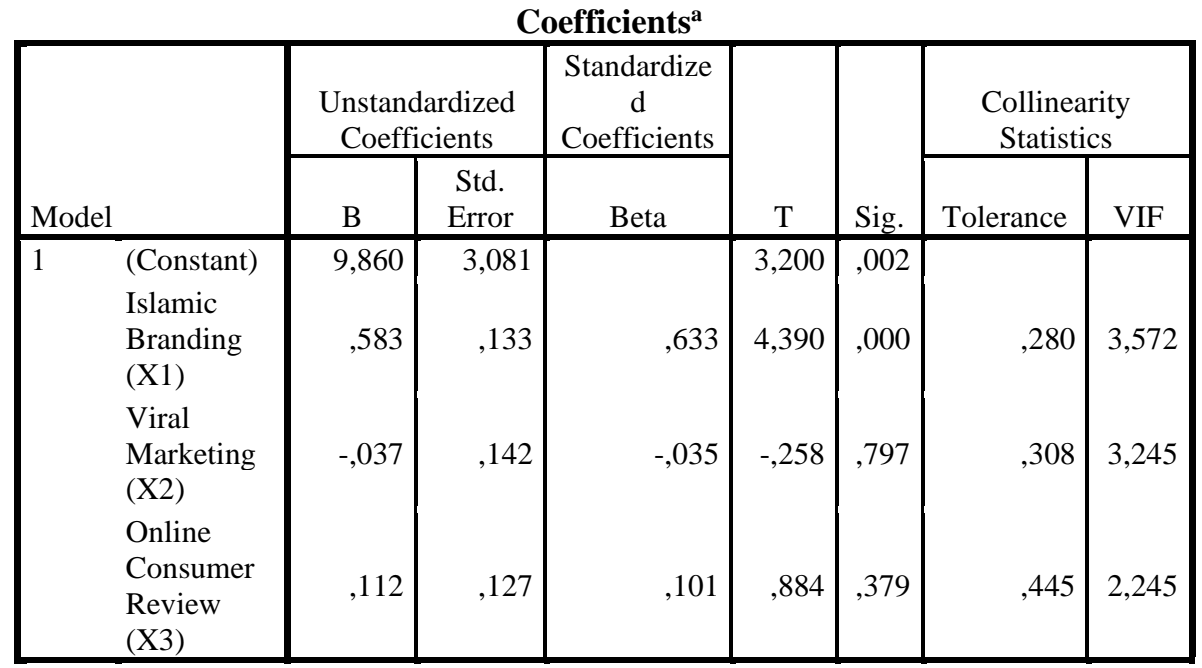

a. Dependent Variable: Purchase Intention $(\mathrm{Z})$

Source: Primary data is processed, 2021 


\section{$A I \overline{I E B}$ Annual International Conference \\ on Islamic Economics and Business, 2021}

From table 5 above, it can be seen that all variables have a tolerance value $>0.10$ and a VIF value $<10$, meaning that this regression model is free from multicollinearity.

\subsubsection{Heteroscedasticity Test (Equation 1)}

Table 6. Heteroscedasticity Test Results Equation 1

Coefficients $^{\mathbf{a}}$

\begin{tabular}{|c|c|c|c|c|c|}
\hline \multirow[b]{2}{*}{ Model } & \multicolumn{2}{|c|}{$\begin{array}{l}\text { Unstandardized } \\
\text { Coefficients }\end{array}$} & \multirow{2}{*}{$\begin{array}{c}\begin{array}{c}\text { Standardized } \\
\text { Coefficients }\end{array} \\
\text { Beta } \\
\end{array}$} & \multirow[b]{2}{*}{$\mathrm{T}$} & \multirow[b]{2}{*}{ Sig. } \\
\hline & $\mathrm{B}$ & Std. Error & & & \\
\hline 1 (Constant) & 3,524 & 1,919 & & 1,836 &, 070 \\
\hline Islamic Branding (X1) &,- 100 & ,083 &,- 234 & $-1,209$ & ,230 \\
\hline Viral Marketing (X2) &,- 016 &, 088 &,- 033 &,- 180 & ,857 \\
\hline $\begin{array}{l}\text { Online Consumer Review } \\
\text { (X3) }\end{array}$ & ,076 & ,079 & , 148 & ,964 & ,337 \\
\hline
\end{tabular}

a. Dependent Variable: Abs_Res1

Source: Primary data is processed, 2021

From table 6 above, it can be seen that the significance value for the variable Islamic Branding (X1) 0.230, Viral Marketing (X2) 0.857 and Online Consumer Review (X3) 0.337 are all greater than 0.05 , meaning that there is no symptom of heteroscedasticity.

\subsubsection{Normality Test (Equation 1)}

Table 7. Normality Test Results Equation 1 One-Sample Kolmogorov-Smirnov Test

\begin{tabular}{|ll|r|}
\hline & & \multicolumn{2}{|l|}{ Unstandardized } \\
& Residual \\
\hline $\mathrm{N}$ & Mean & 96 \\
Normal Parameters ${ }^{\mathrm{a}, \mathrm{b}}$ & Std. Deviation &, 0000000 \\
& Absolute & 3,21617019 \\
Most Extreme Differences &, 056 \\
& Positive &, 056 \\
& Negative &,- 048 \\
Test Statistic & &, 056 \\
Asymp. Sig. (2-tailed) & &, $200^{\mathrm{c}, \mathrm{d}}$ \\
\hline
\end{tabular}

Source: Primary data is processed, 2021

From table 7 above, it can be explained that the significant value is 0.200 greater than 0.05 , meaning that the data for each variable is normally distributed.

\subsubsection{Multicollinearity Test (Equation 2)}

Table 8. Multicollinearity Test Results Equation 2

Coefficients ${ }^{\mathrm{a}}$

\begin{tabular}{|c|c|c|c|c|c|c|c|}
\hline \multirow[b]{2}{*}{ Model } & \multicolumn{2}{|c|}{$\begin{array}{c}\text { Unstandardized } \\
\text { Coefficients }\end{array}$} & \multirow{2}{*}{$\begin{array}{c}\text { Standardized } \\
\text { Coefficients }\end{array}$} & \multirow[b]{2}{*}{$\mathrm{T}$} & \multirow[b]{2}{*}{ Sig. } & \multicolumn{2}{|c|}{$\begin{array}{l}\text { Collinearity } \\
\text { Statistics }\end{array}$} \\
\hline & $\mathrm{B}$ & Std. Error & & & & Tolerance & VIF \\
\hline 1 (Constant) & $-1,753$ & 2,188 & &,- 801 & , 425 & & \\
\hline $\begin{array}{l}\text { Islamic Branding } \\
\text { (X1) }\end{array}$ & ,531 & ,098 & ,524 & 5,403 & , 000 & ,231 & 4,320 \\
\hline
\end{tabular}




\section{$A I \overline{C E B} \quad$ Annual International Conference \\ on Islamic Economics and Business, 2021}

\begin{tabular}{l|r|r|r|r|r|r|r|}
\hline $\begin{array}{l}\text { Viral Marketing } \\
\text { (X2) }\end{array}$ &, 276 &, 096 &, 243 & 2,888 &, 005 &, 308 & 3,247 \\
$\begin{array}{l}\text { Online Consumer } \\
\text { Review (X3) }\end{array}$ &,- 030 &, 086 &,- 025 &,- 350 &, 727 &, 442 & 2,264 \\
$\begin{array}{l}\text { Purchase Intention } \\
\text { (Z) }\end{array}$ &, 264 &, 070 &, 240 & 3,758 &, 000 &, 536 & 1,865 \\
\hline
\end{tabular}

a. Dependent Variable: Purchasing Decisions (Y)

Source: Primary data is processed, 2021

From table 8 above, it can be seen that all variables have a tolerance value $>0.10$ and a VIF value $<10$, meaning that this regression model is free from multicollinearity.

\subsubsection{Heteroscedasticity Test (Equation 2)}

Table 9. Heteroscedasticity Test Results Equation 2

Coefficients $^{\mathrm{a}}$

\begin{tabular}{|c|c|c|c|c|c|}
\hline \multirow[b]{2}{*}{ Model } & \multicolumn{2}{|c|}{$\begin{array}{c}\text { Unstandardized } \\
\text { Coefficients }\end{array}$} & \multirow{2}{*}{$\begin{array}{c}\text { Standardized } \\
\text { Coefficients }\end{array}$} & \multirow[b]{2}{*}{$\mathrm{t}$} & \multirow[b]{2}{*}{ Sig. } \\
\hline & $\mathrm{B}$ & Std. Error & & & \\
\hline 1 (Constant) & 2,623 & 1,376 & & 1,907 &, 060 \\
\hline Islamic Branding (X1) &,- 075 & ,062 &,- 25 & $1,218^{-}$ & ,226 \\
\hline Viral Marketing (X2) &,- 057 & 060 &,- 17 &,- 948 & ,346 \\
\hline $\begin{array}{l}\text { Online Consumer Review } \\
\text { (X3) }\end{array}$ & 083 &, 054 & ,23 & 1,539 & , 127 \\
\hline Purchase Intention $(\mathrm{Z})$ & 011 & ,044 & ,03 & ,257 & ,798 \\
\hline
\end{tabular}

a. Dependent Variable: Abs_Res2

Source: Primary data is processed, 2021

From table 9 above, it can be seen that the significance value for the variable Islamic Branding (X1) 0.226, Viral Marketing (X2) 0.346, Online Consumer Review (X3) 0.127 and Purchase Interest $(\mathrm{Z}) 0.798$ are all greater than 0.05 , meaning that they are not heteroscedasticity occurs.

\subsubsection{Normality Test (Equation 2)}

Table 10. Smirnov Normality Test Results Equation 2

One-Sample Kolmogorov-Smirnov Test

\begin{tabular}{|ll|r|}
\hline & & $\begin{array}{c}\text { Unstandardized } \\
\text { Residual }\end{array}$ \\
\hline $\mathrm{N}$ & Mean & 96 \\
Normal Parameters &, 0000000 \\
& Std. Deviation & 2,15494322 \\
Most Extreme Differences & Absolute &, 073 \\
& Positive &, 049 \\
& Negative &,- 073 \\
Test Statistic & &, 073 \\
Asymp. Sig. (2-tailed) & &, $200^{\mathrm{c}, \mathrm{d}}$ \\
\hline
\end{tabular}

Source: Primary data is processed, 2021 


\section{$A I C \overline{I E B} \quad$ Annual International Conference \\ on Islamic Economics and Business, 2021}

From table 10 above, it can be explained that the significant value is 0.200 greater than 0.05 , meaning that the data for each variable is normally distributed.

\subsubsection{Path Analysis Test}

To be able to determine the effect generated by the intervening variable, it is necessary to use Path analysis test. Path analysis is the development of multiple linear regression analysis, it can be said that path analysis is the use of regression analysis to estimate causal relationships between variables that have been previously established on the basis of existing theories (Ghozali, 2013). The following is a chart table of path analysis results:

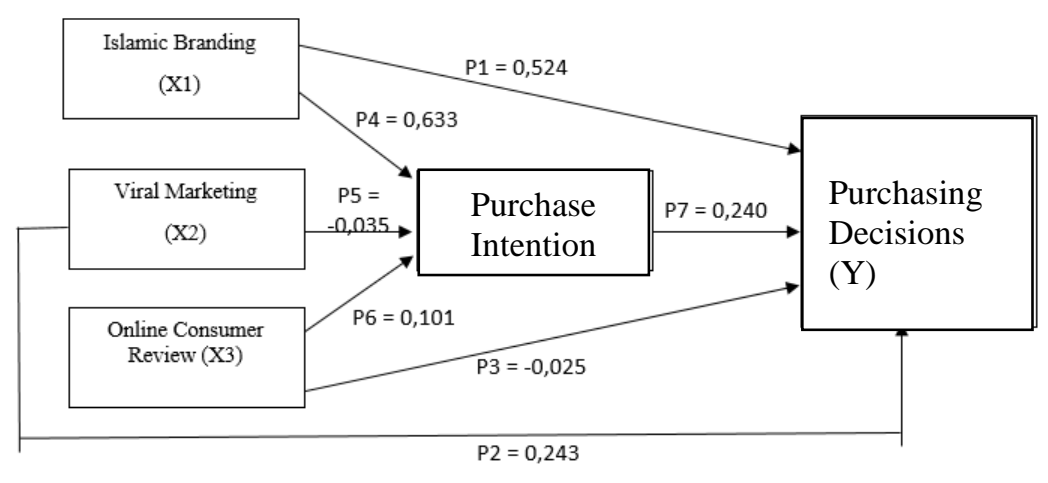

Fig 2. Path Analysis Model

1) The Influence of Islamic Branding on Purchase Decisions with Purchase Intention as an Intervening Variable

$$
\begin{aligned}
& S p 2 p 3=\sqrt{p 3^{2} S p 2^{2}+p 2^{2} S p 3^{2}+S p 2^{2} S p 3^{2}} \\
& =\sqrt{\begin{array}{c}
(0,264)^{2}(0,133)^{2}+(0,583)^{2}(0,070)^{2}+(0,133)^{2} \\
(0,070)^{2}
\end{array}} \\
& =\sqrt{\begin{array}{c}
(0,069696)(0,017689)+(0,339889) \\
(0,0049)+(0,017689)(0,0049)
\end{array}} \\
& =\sqrt{\begin{array}{c}
0,001232852544+0,0016654561+ \\
0,0000866761
\end{array}} \\
& =\sqrt{0,002984984744} \\
& =0,0546350139013
\end{aligned}
$$

Based on the results of the $\mathrm{Sp} 2 \mathrm{p} 3$ we can calculate the value of $\mathrm{t}$ count:

$$
t=\frac{p 4 p 7}{S p 2 p 3}=\frac{(0,633)(0,240)}{0,0546350139013}=\frac{0,15192}{0,0546350139013}=2,780634
$$

From the Sobel test calculation above, it is known that the $\mathrm{r}$ count is $2.780634>\mathrm{t}$ table 1.66159 which means it is significant. This informs that purchase intention $(Z)$ can mediate the influence of Islamic branding (X1) on purchase decision (Y). 
2) The Effect of Viral Marketing on Purchase Decisions with Purchase Intention as an Intervening Variable.

$$
\begin{aligned}
S p 2 p 3 & =\sqrt{p 3^{2} S p 2^{2}+p 2^{2} S p 3^{2}+S p 2^{2} S p 3^{2}} \\
& =\sqrt{\begin{array}{c}
(0,264)^{2}(0,142)^{2}+(-0,037)^{2}(0,070)^{2}+(0,142)^{2} \\
(0,070)^{2}
\end{array}} \\
& =\sqrt{\begin{array}{c}
(0,069696)(0,020164)+(0,001369) \\
(0,0049)+(0,020164)(0,0049)
\end{array}} \\
& =\sqrt{\begin{array}{c}
0,001405350144+0,0000067081+ \\
0,0000988036
\end{array}} \\
& =\sqrt{0,001510861844} \\
& =0,0388698063283
\end{aligned}
$$

Based on the results of the Sp2p3 we can calculate the value of $t$ count:

$$
t=\frac{p 5 p 7}{S p 2 p 3}=\frac{(-0,035)(0,240)}{0,0388698063283}=\frac{-0,0084}{0,0388698063283}=-0,216106
$$

From the Sobel test calculation above, it is known that $r$ count is $-0.216106<t$ table 1.66159 which means it is not significant. This informs that purchase intention $(Z)$ cannot mediate the effect of viral marketing (X2) on purchase decision (Y).

3) Effect of Online Consumer Review on Purchase Decisions with Purchase Intention as Intervening Variable

$$
\begin{aligned}
S p 2 p 3 & =\sqrt{p 3^{2} S p 2^{2}+p 2^{2} S p 3^{2}+S p 2^{2} S p 3^{2}} \\
& =\sqrt{\begin{array}{c}
(0,264)^{2}(0,127)^{2}+(0,112)^{2}(0,070)^{2}+(0,127)^{2} \\
(0,070)^{2}
\end{array}} \\
& =\sqrt{\begin{array}{c}
(0,069696)(0,016129)+(0,012544) \\
(0,0049)+(0,016129)(0,0049)
\end{array}} \\
& =\sqrt{\begin{array}{c}
0,001124126784+0,0000614656+ \\
0,0000790321
\end{array}} \\
& =\sqrt{0,001264624484} \\
& =0,0355615590771
\end{aligned}
$$

Based on the results of the $\mathrm{Sp} 2 \mathrm{p} 3$ we can calculate the value of $\mathrm{t}$ count:

$$
t=\frac{p 6 p 7}{S p 2 p 3}=\frac{(0,101)(0,240)}{0,0355615590771}=\frac{0,02424}{0,0355615590771}=-0,681634
$$

From the Sobel test calculation above, it is known that $r$ count is $0.681634<\mathrm{t}$ table 1.66159 which means it is not significant. This informs that purchase intention $(Z)$ cannot mediate the influence of online consumer review (X3) on purchase decision (Y). 


\section{$A I C \overline{I E B}$ Annual International Conference \\ on Islamic Economics and Business, 2021}

\section{References}

Agustyan, R., \& Baehaqi, M. (2020). Analisis Pengaruh Online Consumer Review, Warranty Product dan Brand Trust Terhadap Purchase Decision Smartphone Xiaomi di Kabupaten Kebumen. Jurnal Ilmiah Mahasiswa Manajemen, Bisnis Dan Akuntansi (JIMMBA), 2(2), 240-250. https://doi.org/10.32639/jimmba.v2i2.468

APJJI. (2020). Pengguna Internet Indonesia Hampir Tembus 200 Juta di 2019- Q2 2020. blog.apjii.or.id

Chou, S. Y. (2012). Online Reviews and Pre-Purchase Cognitive Dissonance : A Theoretical Framework and Research Propositions. Journal of Emerging Trends in Computing and Information Sciences, 3(2), 199-204.

Damayanti, R. S. (2019). Pengaruh Online Customer Review And Rating , E-Service Quality Dan Price Terhadap Minat Beli Tahun 2019 Pada Fakultas Ekonomi dan Bisnis. Universitas Muhammadiyah Magelang.

Dobele, A., Toleman, D., \& Beverland, M. (2005). Controlled infection! Spreading the brand message through viral marketing. Business Horizons, 48(2), 143-149. https://doi.org/10.1016/j.bushor.2004.10.011

Febriana, M., \& Yulianto, E. (2018). Pengaruh Online Consumer Revew Oleh Beauty Vlogger Terhadap Keputusan Pembelian (Survei Pada Mahasiswi Fakultas Ilmu Administrasi Universitas Brawijaya Angkatan 2014/2015 Dan 2015/2016 Yang Membeli Dan Menggunakan Purbasari Matte Lipstick). Jurnal Administrasi Bisnis (JAB), 58(1), 1-9.

Furqon, M. A. (2020). Pengaruh Viral Marketing dan Turbo Marketing Terhadap Keputusan Pembelian. Jurnal Inspirasi Bisnis Dan Manajemen, 4(1), 79. https://doi.org/10.33603/jibm.v4i1.3311

Ghozali, I. (2013). Aplikasi Analisis Multivariate dengan Program IBM SPSS 21 (7th ed.). Badan Penerbit Universitas Diponegoro.

GNFI. (2021). Sengitnya Perebutan Takhta Penguasa E-Commerce di Tanah Air. Good News From Indonesia.

Hidayati, D. A. (2018). Analisis Pengaruh Islamic Branding Dan Nilai Religiusitas Terhadap Keputusan Konsumen Muslim Dalam Pemilihan Hotel (Studi Kasus Pada Hotel Semesta Semarang). UIN Walisongo Semarang.

Katadata. (2020). Industri Halal untuk Semua. katadata.co.id

Kotler, P. (2005). Manajemen Pemasaran Jilid 1. Gramedia.

Kotler, P., \& Keller, K. L. (2008). Manajemen Pemasaran Jilid 2 (13th ed.). Erlangga.

Kotler, P., \& Keller, K. L. (2009). Manajemen Pemasaran Jilid 1. Pearson Education Limited.

Lackermair, G., Kailer, D., \& Kanmaz, K. (2013). Importance of Online Product Reviews from a Consumer's Perspective. Advances in Economics and Business, 1(1), 1-5. https://doi.org/10.13189/aeb.2013.010101

Maulani, L. S., \& Sanawiri, B. (2019). Pengaruh Social Media Marketing Terhadap Brand Awareness Serta Dampaknya Pada Purchase Decision (Survei Online pada Followers Aktif Instagram dan Facebook Vauza Tamma Hijab). Jurnal Administrasi Bisnis, $72(2)$, 148-156. http://administrasibisnis.studentjournal.ub.ac.id/index.php/jab/article/view/2877/3262

Mo, Z., Li, Y.-F., \& Fan, P. (2015). Effect of Online Reviews on Consumer Purchase Behavior. Journal of Service Science and Management, 08(03), 419-424. https://doi.org/10.4236/jssm.2015.83043

Montjai, O., Tewal, B., \& Lengkong, V. P. K. (2014). Motivasi, Sikap Dan Minat Beli Konsmen Pengaruhnya Terhadap Keputusan Pembelian Sepeda Motor Yamaha Pt. Hasjrat Abadi Sentral Yamaha Manado. Jurnal EMBA, 2(4), 35-45. 


\section{$A I \overline{C E B}$ Annual International Conference \\ on Islamic Economics and Business, 2021}

Morissan, M. (2012). Periklanan (Komunikasi Pemasaran Terpadu). Kencana Prenada Media Grup.

Nasrullah, M. (2015). Islamic Branding, Religiusitas Dan Keputusan Konsumen Terhadap Produk. Jurnal Hukum Islam, 13(2), 79. https://doi.org/10.28918/jhi.v13i2.487

Nggilu, M., Tumbel, A. L., \& Djemly, W. (2019). Pengaruh Viral Marketing, Celebrity Endorser, Dan Brand Awareness Terhadap Keputusan Pembelian Pada Geprek Bensu Manado. Jurnal EMBA: Jurnal Riset Ekonomi, Manajemen, Bisnis Dan Akuntansi, 7(3), 2691-2700. https://doi.org/10.35794/emba.v7i3.23720

Octaviani, W. (2021). Pengaruh Product Quality, Sales Promotion, Dan Islamic Branding Terhadap Keputusan Pembelian Secara Online ( Studi Kasus Brand Naisha). IAIN Salatiga.

Prihanti, D. (2019). Pengaruh E-Service Quality, Islamic Branding dan Islamic Advertising Ethics terhadap Keputusan Pembelian (Studi Kasus pada Konsumen Shopee di Indonesia) [IAIN Salatiga]. http://e-repository.perpus.iainsalatiga.ac.id/id/eprint/5645

Purwanto, J. (2019). Pengaruh Celebrity Endorser, Kepercayaan Dan Viral Marketing Terhadap Keputusan Pembelian Di Instagram (Studi Kasus Pada Mahasiswa Universitas Mercu Buana). Universitas Mercu Buana.

Rakhma, A. F., Pardiman, \& Hatneny, A. I. (2021). Pengaruh Product Knowledge, Brand Image, Dan Online Customer Review Terhadap Keputusan Pembelian Di Marketplace Shopee (Studi pada Customer Marketplace Shopee di Malang). E - Jurnal Riset Manajemen Prodi Manajemen, 2020, 82-94.

Rauniar, R., Rawski, G., Yang, J., \& Johnson, B. (2014). Technology acceptance model (TAM) and social media usage: An empirical study on Facebook. Journal of Enterprise Information Management, 27(1), 6-30. https://doi.org/10.1108/JEIM-04-2012-0011

Sari, S. (2019). Pengaruh Kelompok Referensi, Online Customer Review Dan Citra Merek Terhadap Minat Beli Dan Keputusan Pembelian (Studi Pada Konsumen Generasi Milenial Natasha Skin Clinic Center) [Universitas Muhammadiyah Magelang]. http://eprintslib.ummgl.ac.id/

Schiffman, \& Kanuk. (2008). Perilaku Konsumen (Edisi 7). Indeks.

Shopee. (2021). Shopee is the leading e-commerce platform in Southeast Asia. Shopee Limited. careers.shopee.co.id

Simanjuntak, M., \& Sukresna, I. M. (2020). Peningkatan Kinerja Pemasaran Digital Melalui Technology Acceptance Model. Prosiding The 11th Industrial Research Workshop and National Seminar, 11(1), 786-792.

Skrob, J. (2005). Open Source and Viral Marketing. FH Kufstein Austria.

Solihin, D. (2020). Pengaruh Kepercayaan Pelanggan Dan Promosi Terhadap Keputusan Pembelian Konsumen Pada Online Shop Mikaylaku Dengan Minat Beli Sebagai Variabel Intervening. Jurnal Mandiri : Ilmu Pengetahuan, Seni, Dan Teknologi, 4(1), 38-51. https://doi.org/10.33753/mandiri.v4i1.99

Sriyanto, A., \& Kuncoro, A. W. (2019). Pengaruh brand ambassador, minat beli dan testimoni terhadap keputusan pembelian. Jurnal Ekonomika Dan Manajemen, 8(1), 21-34.

Sugiyono. (2013). Metode Penelitian Kuantitatif, Kualitatif, dan R\&D. Alfabeta.

Tjiptono. (2001). Strategi Pemasaran (1 (ed.)). Andi.

Trishananto, Y. (2019). Islamic branding, religiosity and consumer decision on products in IAIN Salatiga. Indonesian Journal of Islamic Economics Research, 1(2), 93-100. https://doi.org/10.18326/ijier.v1i2.3145

Yunus, N. S. N. M., Rashid, W. E. W., Ariffin, N. M., \& Rashid, N. M. (2014). Muslim's Purchase Intention towards Non-Muslim's Halal Packaged Food Manufacturer. Procedia - Social and Behavioral Sciences, 130, 145-154. https://doi.org/10.1016/j.sbspro.2014.04.018 